\title{
Activism and Environmentalism in British Rock Music: the Case of Radiohead.
}

Radiohead: militantisme, écologie et rock britannique

\section{Guillaume Clément}

\section{(2) OpenEdition}

\section{Journals}

Electronic version

URL: http://journals.openedition.org/rfcb/1499

DOI: $10.4000 /$ rfcb. 1499

ISSN: 2429-4373

\section{Publisher}

CRECIB - Centre de recherche et d'études en civilisation britannique

Electronic reference

Guillaume Clément, « Activism and Environmentalism in British Rock Music: the Case of Radiohead. », Revue Française de Civilisation Britannique [Online], XXII-3 | 2017, Online since 06 July 2017, connection on 10 December 2020. URL : http://journals.openedition.org/rfcb/1499 ; DOI : https://doi.org/ $10.4000 /$ rfcb. 1499

This text was automatically generated on 10 December 2020.

Revue française de civilisation britannique est mis à disposition selon les termes de la licence Creative Commons Attribution - Pas d'Utilisation Commerciale - Pas de Modification 4.0 International. 


\section{Activism and Environmentalism in British Rock Music: the Case of Radiohead.}

Radiohead: militantisme, écologie et rock britannique

Guillaume Clément

\section{Introduction}

1 Radiohead are one of the most revered contemporary rock bands in Britain, having achieved considerable commercial success while also forging their own path beyond the traditional borders of guitar-based rock music. The band were formed in the late 1980s by a group of five childhood friends who had met at a private school in Abingdon (Oxfordshire): singer/guitarist Thom Yorke, guitarist Ed O'Brien, drummer Phil Selway, bassist Colin Greenwood, and his brother Jonny, a multi-instrumentalist. As of May 2016, six of Radiohead's nine albums (OK Computer, Kid A, Amnesiac, Hail To The Thief, In Rainbows, and A Moon Shaped Pool) have reached the top spot in the official UK charts ${ }^{1}$ and received multiple platinum certifications by the British Phonographic Industry, ${ }^{2}$ indicating sales ranging between 600,000 and 3 million units for each album in the UK alone. Radiohead have been praised by their large international fan base and by the music press for their cultural relevance, their taste for musical experimentation, and, more recently, for some of the band members' political activism.

Indeed, the band's frontman, Thom Yorke, has come to be known as an advocate for environmental protection and climate change awareness, going so far as to play fundraising concerts for the Green Party and attend international environmental summits. While this could simply be perceived as yet another celebrity using his resources and influence to push for political change, Yorke's activism can hardly be dissociated from his band's music, more particularly their lyrics, which often reflect political concerns. However, in their interviews, Radiohead members have occasionally dismissed any notion that their music should be interpreted as overly political. For 
instance, the band's sixth album bears the title Hail To The Thief and was therefore interpreted by many as an open criticism of George W. Bush's controversial election in 2000 by using a popular slogan used to mock the President-elect at the time. Yet Thom Yorke attempted to deny the political interpretation of the album's title in several interviews:

With Hail To The Thief, the whole thing about it being political is a bit far-fetched. I keep reading stuff now about how this album is all about politics and antiAmerica... just because of the title and one or two quotes I gave. People overreact, read things into stuff, look for an angle. This record, to me, these new songs, they're not so much songs about politics as me desperately struggling to keep politics out. The past year... If I could have written about anything else, I would have. But how can any sensible person ignore what's been going on altogether? I really couldn't. I would love to write lyrics free of politics! ${ }^{3}$

Yet in reading this quote the attempt at denying the political intent of the album and its title appears as quite feeble, and even Yorke himself later acknowledged that keeping politics out of his music was impossible in such a context.

4 As a commercially successful band, Radiohead potentially retain the ability to use their music as a means to convey political messages, and in spite of their denial, their music may be considered as a potential gateway for the audience into the band's politics, which assumes its full potential in Yorke's personal activism. This paper will explore the roots of Radiohead's political thought throughout their career, especially by taking their songs and lyrics as a starting point, and highlight how a taste for experimentation and cryptic yet political - songs blossomed into personal activism. A sense of continuity between the music, the lyrics and personal political participation will be underlined throughout the study of Radiohead's most popular albums.

\section{Popular music and political meaning: the role of the historical context}

5 The works of Simon Frith, author of The Sociology of Rock, stress the relevance of historical context when analysing popular music: "From a sociological point of view the history of music must be understood as an aspect of social history; musical changes reflect changes in society." Such a statement can readily be applied to Radiohead, whose work needs to be considered alongside their historical context. The band formed in the middle of the Thatcher years and rose to fame during John Major's premiership but most of their political output and activism spans the latter years of their long career, as most of the politically charged songs which will be studied below were released from 1997 onwards, that is to say under Tony Blair's (and then Gordon Brown's) Labour governments. Since then, Radiohead have continued to be seen as a politically active band, at odds with a number of Conservative policies.

6 Consequently, each album's specific historical context helps shape -- more or less directly -- the songs' lyrical content.Joseph Tate quotes a 2003 interview with the New Musical Express (or NME, Britain's leading popular music magazine), in which Thom Yorke reveals a surprising approach to songwriting for the Hail To The Thief album, which involves taking into account elements from current events and politics and then rearranging them so as to take them out of their original context: "I was cutting these things out, and deliberately taking them out of context, so they're like wallpaper. Then, when I needed words for 
songs I'd be taking them out of this wallpaper, and they were out of any political context at all." ${ }^{5} \mathrm{In}$ the same paper, Tate quotes another interview given by Yorke to Rolling Stone in the United States around the same time, in which he acknowledged the influence of political radio programmes on his songwriting process: "When I started writing these new songs, I was listening to a lot of political programmes on BBC Radio 4. I found myself... writing down little nonsense phrases, those Orwellian euphemisms that our government and yours are so fond of. They became the background of the record." ${ }^{16}$ So Yorke concedes that, in Radiohead's case, removing the political context from the songs is indeed impossible, but by the same token, the songwriter is using it in his own personal way to build the lyrics. Knowledge of a song's historical background may then prove necessary for the audience to make sense of it and to grasp the fullness of its political commentary.

\section{OK Computer, or "Cruel Britannia"}

7 From OK Computer onwards, a visible political streak has permeated Radiohead's work. According to biographer Martin Clarke ${ }^{7}$, the band found inspiration in Will Hutton's The State We're In, in which the author lambasted the impact of Thatcherite policies on contemporary Britain. At the same time, Thom Yorke delved into some of Noam Chomsky's work, including Manufacturing Consent, ${ }^{9}$ which depicted American mass media as ideological machines essentially carrying out a function of propaganda. Such highly political influences can be felt throughout $O K$ Computer's lyrics, which generally paint quite a grim picture of British society. One of its most striking tracks is "No Surprises", which was released as a single in 1998 and reached the top five of the singles' charts. The song starts off as a lullaby-like melody played on glockenspiel and acoustic guitar, whose gentleness clashes with the depressingly bleak imagery of the lyrics which encourage people either to "bring down the government" or to live a miserable, meaningless life:

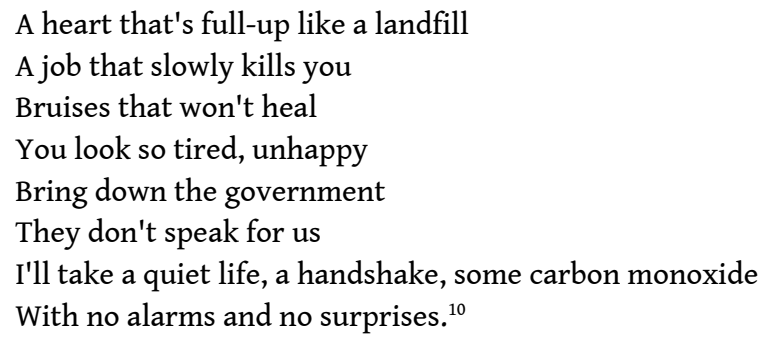

One of the most outstanding tracks on the album remains "Fitter Happier", a piece which is less than two minutes long and features very little music per se, but rather electronic soundbites and sparse chords played on piano and strings, while the lyric is delivered by a computer-generated voice. The text itself consists in a cynical collage of slogans which seem to have been taken straight out of infomercials and public service announcements promoting a healthy lifestyle, while more depressing slogans are progressively inserted into the text:

Fitter, happier, more productive, comfortable, not drinking too much

Regular exercise at the gym (three days a week)

Getting on better with your associate employee contemporaries

At ease, eating well (no more microwave dinners and saturated fats)

A patient better driver, a safer car (baby smiling in back seat) [...]

Will frequently check credit at (moral) bank (hole in wall)

Favours for favours, fond but not in love

Charity standing orders, on Sundays ring road supermarket [...] 
Now self-employed, concerned (but powerless)

An empowered and informed member of society (pragmatism not idealism) [...]

Still cries at a good film, still kisses with saliva

No longer empty and frantic like a cat tied to a stick

That's driven into frozen winter shit (the ability to laugh at weakness)

Calm, fitter, healthier and more productive

A pig in a cage on antibiotics. ${ }^{11}$

In the world depicted by Radiohead, citizens are given the impression that they have a political role to play, yet this power is all but empty. The text's unique syntactic structure, featuring very few conjugated verbs but more noun groups and participles, suggests that in such a society, individuals make no decisions for themselves, and that they are best defined as consumers rather than citizens - a fact which is mirrored in the use of commercial-type slogans and platitudes delivered by a synthetic voice.

What is even more striking with OK Computer is the timing of its release and the contrast it presents with the Cool Britannia phenomenon and Labour's landslide victory in May 1997, all the more so as the eighth track on the album, "Electioneering", seems to take issue with the type of empty pledges and ploys which candidates resort to in order to gain votes:

I will stop, I will stop at nothing

Say the right things when electioneering

I trust I can rely on your vote

When I go forwards, you go backwards

Somewhere we will meet

Riot shields, voodoo economics

Cattle prods and the IMF

I trust I can rely on your vote. ${ }^{12}$

Set to the sound of an aggressive, twitchy guitar riff, "Electioneering"'s lyrics eerily sound like extracts from a conversation that a candidate might have been having - off the record of course - with potential voters in the build-up to the 1997 General Election. Tony Blair, for instance, had gone to great lengths to "rely on the votes" of many a celebrity supporter, including members of fellow British rock bands Oasis, Blur and Pulp, or even Manchester United's coach, Sir Alex Ferguson, to name but a few. ${ }^{13}$ Towards the end of the text, references become more openly political,by referring to the International Monetary Fund, or by poking fun at Ronald Reagan's conservative economic policy (through the allusion to "voodoo economics"). But these references are neither precise nor developed; they are merely pasted alongside other images of protest or violence to further highlight the band's resentment. While "Electioneering"'s lyrics undoubtedly succeed in highlighting the hypocrisy of political leaders on the campaign trail, the relatively cryptic nature of the political references and the laconic style of the lyric (inherent to the "cut-paste" technique admittedly used by Yorke when writing his texts) in "No Surprises" and "Fitter happier" further relegate to the background the construction of a more thorough political ideology which might be expected of a fullyfledged protest song.

In spite of a perceived lack of political depth or clarity, OK Computer nonetheless remains a strikingly coherent album in that several of its songs paint a bleak picture of British society - at odds with the notion of Cool Britannia ${ }^{14}$ which, at the time, pervaded the nation's successful cultural industries. While British musicians, designers or artists (like Damien Hirst or Tracey Emin) were being celebrated the world over, Radiohead chose to focus on a more realistic picture of their homeland, closer perhaps to the notion of Cruel 
Britannia, ${ }^{15}$ in which people are defined more as consumers than citizens and where political manipulation is rife. Despite the unsettling images conjured up by such political references, the album was hailed as a masterpiece and proved a commercial success: upon release, it reached the number one spot in the UK album charts and remained in the charts for two years, indicating sales in excess of 2.5 million in the UK alone (with 3 million extra units being sold in the United States). Radiohead also received several accolades for this third effort, including a Grammy Award in the United States, and to this day OK Computer has been consistently ranked in lists of "best albums ever" in the music press. The album's success indicates that subversive music and commercial success are not necessarily incompatible, and that the audience Radiohead reached out to either agreed with the band's message, or, at the very least, that they were not deterred by it.

\section{Kid A and Amnesiac: "Did you lie to us, Tony?"} (released only a few months apart in 2000 and 2001), and gave way to a dramatic change in their songwriting approach by largely eschewing guitars and veering towards more experimental, electronic music. As was the case with OK Computer, the historical context of the recording sessions prompted the band to incorporate references to political concepts into their music. According to Martin Clarke, ${ }^{16}$ Thom Yorke was, at the time, reading Naomi Klein's No $\operatorname{Logo}^{17}$ (a book that calls for the opposition to capitalist brands and globalisation) which directly influenced the peculiar commercial strategy that surrounded Kid A's release. The album was indeed shrouded in mystery until its release date while the band refused to polish any of the album's songs into a single that their record company might deem marketable. Radio stations were therefore free to choose any of the album's tracks to add to their playlists and several listeners were taken aback by the relative absence of guitars or of the more traditional rock sounds with which some had come to associate Radiohead's earlier work.

Lyrically speaking, the atmosphere created on both albums still relies on cryptic phrases, or "euphemisms" as Yorke would call them, thus making it more difficult for the listener to make sense of the lyrics, on a political level at least, than with OK Computer's. Yet, one specific track on Amnesiac, "You And Whose Army?", is often highlighted by fans and critics as a potential attack on Tony Blair himself, even though its release date pre-dates the events it may take issue with:

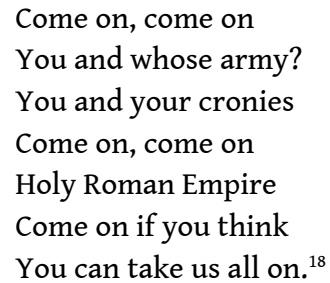

A listener might be tempted (and many have indeed been) to interpret these words as a criticism of the United States' so-called imperialist policy (which could be a reference concealed in the allusion to the Holy Roman Empire), and the invasion of Iraq, which required the support of their British "cronies". Yet, this song was released in June 2001, that is to say almost two years before Operation Iraqi Freedom was launched. In an interview with British rock magazine Mojo in June 2001, Thom Yorke simply confessed that "the song's ultimately about someone who is elected into power and who then blatantly 
betrays them - just like Blair did". ${ }^{19}$ While the betrayal in question may not have specifically arisen from Britain's foreign policy at the time, a feeling of disappointment nonetheless pervaded part of the British public at the time, especially in relation to New Labour's pre-1997 promises. Tony Blair's government - the first Labour cabinet in nearly twenty years - was criticised for not delivering on some of its electoral promises and Radiohead, like many Britons, were quite aware of a number of domestic policy issues. On March $14^{\text {th }}$, 1998, the New Musical Express chose to run a picture of Tony Blair on its front page, with the following headline, "Ever Get The Feeling You've Been Cheated?" 20 and a list of grievances as follows: "welfare to work, student tuition fees, no debate on drugs, curfews". The welfare-towork scheme (also known as New Deal) was aimed at helping the unemployed find work through training opportunities, but also threatened to cut the benefits of certain jobseekers. The Labour government was also criticised for introducing university tuition fees, first implemented in September 1998. In many respects, this particular issue of the NME voiced the concerns of part of the youth and the music industry concerning policies which were deemed too conservative for a Labour government.

While Radiohead were not featured in this issue of the $N M E,{ }^{21}$ Thom Yorke and his bandmates certainly shared this feeling of disappointment. Even though no specific song on Kid A or Amnesiac seems to be explicitly political ("You And Whose Army?" aside), the band did try to voice their resentment in "Follow Me Around", an unreleased song which was played live on occasion over the course of subsequent tours and concerts, most notably during a live event for BBC Radio 1 recorded at Maida Vale studios on December 8 th $2003 .{ }^{22}$ In the absence of an official recording of the song, some variations can be noted in the lyrics from one live performance to another, but the following lines were consistently featured:

Did you lie to us, Tony?

We thought you were different

Now you know we're not so sure.

17 The phrase "Did you lie to us Tony?" was also featured on the band's official website front page for a few days around March $19^{\text {th }}, 2005$, in the midst of protests which were underway to mark the second anniversary of the invasion of Iraq by American and British troops. Therefore, where OK Computer's political message consisted in a general attack against the hypocrisies of the consumer society, the Kid A / Amnesiac era further illustrated the band's opposition to consumerism and, however implicitly, their resentment of some New Labour policies.

\section{Hail To The Thief: Blair, Bush and the Iraq War}

Such songs as "You And Whose Army?" and "Follow Me Around" indicate that soon after 1997 Tony Blair was already in Radiohead's sights and both tracks undeniably paved the way for the next album, Hail To The Thief, which was released on June $9^{\text {th }}, 2003$ - only a few weeks after the invasion of Iraq. The title is, in itself, a reference to a popular slogan used by protesters who contested George W. Bush's election as President of the United States in 2000, especially during his subsequent swearing-in ceremony in January 2001. The Republican candidate had not gained the majority of the popular vote nationwide but had won the election nonetheless, notably by securing a crucial yet controversial victory in the state of Florida. This slogan (a play on words parodying the official Presidential 
anthem entitled "Hail To The Chief") is also featured in the album's opening track, entitled "2+2=5":

Are you such a dreamer to put the world to rights? [...]

I try to sing along but I get it all wrong, 'cause I'm not

I swat them like flies but like files the buggers keep coming back - Maybe not

All hail to the thief - But I'm not

Don't question my authority or put me in the dock. ${ }^{23}$

Other than the use of the anti-Bush slogan, the lyrics seem to mock a political leader who is depicted as overly ambitious, incompetent, and self-righteous. It should also be noted that the phrase "2+2=5" references George Orwell's Nineteen Eighty-Four, in which this equation stands for a false dogma - another symbol of political manipulation. ${ }^{24}$ In addition, the song's scathing overtones are strengthened by the use of loud, distorted guitar riffs. "2+2=5" remains Hail To The Thief's most straightforward political song, with most other tracks on the record adopting a more subdued tone. Yet, Hail To The Thief continues to be perceived as a political album, due to its title and to the context of its recording and release, which, according to Yorke himself, played a role on the way the lyrics were shaping up.

Since much of Hail To The Thief's political message originated in Britain's foreign policy at the time, a few words need to be said about Thom Yorke's 2006 solo album, The Eraser, which features an intriguing track entitled "Harrowdown Hill" and thus hints once more at the Iraq war. Harrowdown Hill is the name of a place in Oxfordshire where the body of David Kelly, a scientist and United Nations inspector in Iraq, was found in 2003. A few days before his death, Kelly had been identified as the source of a leak to the press which had confirmed that United Nations' inspectors in Iraq had failed to prove the existence of weapons of mass destruction. The cause of his death was officially ruled to be suicide, but some doubts quickly arose as to the autopsy's results, and some physicians (and conspiracy theorists) suggested that Kelly may have been murdered because of his revelations. In his song, Yorke writes from Kelly's point of view and clearly blames the expert's death on the government:

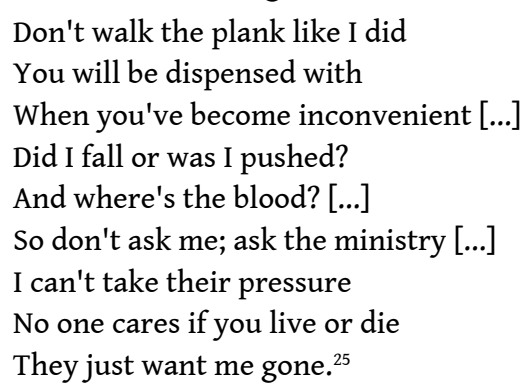

This songs remains, by some measure, the most explicitly political song ever written by Thom Yorke and differs from the classic Radiohead songwriting strategy, in that it does not consist in an obscure collage of politically charged catchphrases, but rather follows a more straightforward narrative. It also focuses on a single issue and relies on more blatant, accessible references, making the song more efficient on the whole.

From OK Computer to The Eraser, Radiohead's lyrics offer an overview of the band's politics: opposition to overblown consumerism (seen as the root of many social issues) and awareness of political manipulation, as illustrated by Britain's participation in the invasion of Iraq. Radiohead's approach in terms of writing lyrics may make it difficult to treat their songs as protest music in the classic sense of the term, given how much of the 
band's political message is intricately dissected into neat political slogans embedded into a generally obscure meaning. However, a protest song could also be described as a track which deals with one or several socio-political issues in order to educate its listeners and, possibly, prompt them to take action. At this point, it seems necessary to draw the line between merely political songs and protest songs. In the words of Michel Prat, the former is a song which "was created in connection with a political event or situation. It can take the shape of an act of resistance [...] or it could be a song which corresponds to a more or less politicized group's ideology." ${ }^{26}$ Within the category of political songs, Michel Prat suggests a further distinction: "There are two types of deliberately political songs: protest songs support a specific political will, while other, essentially satirical, songs aim at ridiculing and/or denouncing a person, a class, or a regime." 27

Radiohead's songs come across as undeniably political but some of them seem to fall more precisely into the satirical category, especially in the band's earlier work. However, the more recent, and fierce, efforts like "You and Whose Army?", "Follow Me Around" or "Harrowdown Hill", should be considered as fully-fledged protest songs, aimed at denouncing the shortcomings of the government of the time. The coherence of the political ideology put forward throughout the band's career makes it possible to call Radiohead an activist band, not only because of the vast audience being reached by their message, but also due to the band members' personal political commitments, ensuring that their words and warnings would not remain simply lyrical.

\section{Personal activism: fulfilling the music's political potential?}

While songwriting has thus far been considered as a form of political action, Radiohead members have also engaged in more traditional types of militancy which have helped cement their reputation as an activist band. Indeed a further look at the band's biographies, media coverage and official website provides several examples of forms of patented political participation, such as taking part in fundraising events for a political group, attending a rally, and contacting an MP or the media about a political issue. ${ }^{28} \mathrm{At}$ the end of the 1990s, members of Radiohead took part in the Tibetan Freedom Concerts organised in New York (1997), Washington DC (1998) and Amsterdam (1999) alongside several popular rock bands of the time including Blur, U2 and Noel Gallagher of Oasis. ${ }^{29}$ The aim of such events was primarily to raise funds for the Tibetan independence movement, but in choosing such well-known artists to perform, the organisers counted on a broad media coverage and a large attendance from these bands' fan-bases in order to raise public awareness as to the plight of the Tibetan people. Through their mere presence at the event, members of Radiohead helped convey a political message to their own fans without taking much risk, since participation in charity concerts remains a fairly mainstream phenomenon among the British rock scene. ${ }^{30}$ Large fundraising festivals have become such frequent events that the biggest names in rock music, like Radiohead, are now almost expected to take part in some of them at least. Radiohead were in fact invited to join the Live 8 festival in 2005 for the benefit of the Make Poverty History campaign, but Thom Yorke declined to join the star-studded line-up, later arguing that "the issues at hand were specifically political and structural, and cannot be fixed by organising a rock concert - a riot, perhaps, but not a rock concert. I didn't feel it 
was appropriate because it was obvious to me that the situation would end up being hijacked for political purposes." ${ }^{131}$ tackle such issues as world hunger and poverty, but also (and perhaps even more crucially) help raise awareness among the bands' sizeable audiences, all of which appears all the more surprising as his band did take part in similar events in the past, and continued to do so later. All the same, Yorke's arguments reflect his own band's stance as it had already filtered through their music - mistrust of traditional politics and the fear of being manipulated or "hijacked". A similar feeling pervades Yorke's refusal to meet with then Prime Minister Tony Blair in 2005 on behalf of environmental non-profit Friends of the Earth to discuss the issue of climate change. Yorke outlined his reasons for declining the invitation in a blog post on Radiohead's official website:

I have no intention of being used by spider spin doctors to make it look like we make progress when it is just words [...]. You'd say, "oh there he goes again interfering and meddling in politics, why doesn't he get on with the music and shut up". Perhaps because I feel a hypocrite if I don't do anything and equally feel a hypocrite if I try getting involved. ${ }^{32}$

This very personal message reveals how difficult it is for a popular musician like Yorke to get involved in politics when his fan-base, and public opinion in general, is likely to judge his every move. Yorke was then torn between the urge to get involved, using his position to fight for environmental protection, and the fear of being manipulated by the government, for instance by being asked to appear alongside the Prime Minister as part of little more than a photo opportunity which would probably lead to no meaningful change in policy. In other words, getting involved politically alongside an environmental organisation remained perfectly fine in Yorke's eyes, but seeing his commitment hijacked by a mainstream political party as part of a public relations campaign would certainly not do. In the months following this blog post, Yorke carried on with his support for Friends of the Earth by becoming a mouthpiece for the organisation's Big Ask campaign, which encouraged citizens to get in touch with their local MPs in order to challenge their views on climate change. In order to show his support, Yorke appeared on video interviews on Friends of the Earth's website and took part in a fundraising concert for the organisation in London on May 1st, 2006, once more accompanied by bandmate Jonny Greenwood. ${ }^{33}$

Concern for the environment then led Thom Yorke to voice his disappointment in the government's energy policy on Radiohead's official website, particularly at the end of 2009, when the Department of Energy and Climate Change announced that ten new nuclear power stations would be built. Yorke reacted to this announcement by posting a cynical rant on his band's website:

Under the confused assumption that we can carry on consuming power as we do now into the future, and too afraid to think out of their own isolated political fuzzy cloud, the British government is committing to build a new round of nuclear power stations for which we don't have the money. Great. Just perfect. Well done fellas. You've really thought about this, haven't you? ${ }^{34}$

This blog post clearly referenced the government's policy and included links to the Greenpeace's and Friends of the Earth's websites, showing a clear intent to educate the band's fans about this issue and to inspire them to take action, for instance by making a donation to these organisations or joining their campaigns. Whether Yorke's involvement made an impact on the band's public remains hard to tell since the evaluation of Radiohead's overall reception by their audiences ${ }^{35}$ remains a complex issue worthy of a

Revue Française de Civilisation Britannique, XXII-3 | 2017 
separate study. Nevertheless the Big Ask campaign can certainly claim to have triggered an actual environmental policy, as the government passed the Climate Change Act in 2008 , pledging to cut its greenhouse gases emissions by $80 \%$ by the year 2050 .

Following these events, Yorke quickly made a habit of posting very personal comments on environmental politics to Radiohead's website, culminating in his coverage of the United Nations climate change conference, organised in Copenhagen in November 2009. Dissatisfied with the lack of progress made there, Thom Yorke posted eight messages to the band's website between November 11th and 19th, while Ed O'Brien, ${ }^{36}$ whose personal outings (let alone political ones) on the band's blog are rare, contributed another article on the subject of climate change as well. Yorke then decided to attend the conference in Copenhagen himself and grew frustrated at the way the talks were turning into a weak negotiation in which each country was trying to propose insignificant carbon emission cuts. Yorke voiced his disappointment in yet another long message:

Yesterday there is [sic] a lot of brinksmanship, the Americans offering money [it] seemed. But no-one was talking 40 percent cuts by 2020 , and the negotiations had an obvious $G 8$ vibe about them, the west dictating terms and bizarrely assuming that the science could be bartered!!! Arguing about who cuts what??? That somehow the amount we have to cut our emissions is negotiable?? What a crock of shit. May I humbly suggest that we remove the professional negotiators who seem to relish the negotiations for their own sake. [Ed] Miliband talked about a hundred square brackets in the document waiting to be filled [...]. What is frustrating so far is America's attitude. Hillary Clinton's speech was apparently still trying to shift responsibility for emissions around... which is just frankly nuts. Obama said nothing though I have not seen all the speech yet. I feel very sad for all Americans I know who hold so much hope for this man. ${ }^{37}$

Other than expressing, once again, the need for significant action to tackle the issue of carbon emissions, this message attacks several politicians by name, including Energy Secretary Ed Miliband, American President Barack Obama and Secretary of State Hillary Clinton. Yorke's concerns were, it seems, justified since the Conference only yielded a non-binding declaration acknowledging the issue of climate change and the need for action to limit temperature increase to $2^{\circ} \mathrm{C}$ globally.

31 Since then, Yorke has moved slightly closer to mainstream politics by offering his support to Tony Juniper, the former director of Friends of the Earth who stood as the Green Party candidate in the Cambridge constituency in the 2010 General Election. Using yet again Radiohead's website to make his announcement and provide details as to a forthcoming benefit concert for the Green Party, Yorke carefully took the time to explain the reasons why he was becoming involved with a party whereas he had refused to meet Tony Blair five years earlier:

I'm doing a low key solo thing at the Cambridge Corn Exchange on the 25th of Feb [ruary]. It's because a friend of mine Tony Juniper (who used to be the head of Friends of the Earth and who I went to the Copenhagen summit with) is hoping to become one of the first Green Members of Parliament in the UK. And I wanted to help him out somehow. I think he'd be a great MP as he knows a lot about the murky brown waters of politics when it comes to the environment, but has positive energy with a healthy contempt for the way they operate. And wouldn't it be nice to have someone there who is actually doing more than paying lip service to climate change? And maybe rip shit up a little? Now normally I wouldn't get involved in politics like this... but let's face it... it ain't Labour or the Tories, is it? [...]. It's a slippery slope, I know [...]. All the proceeds from said event go to the Green Party of which Tony is a member. ${ }^{38}$ 
(t) "be involved in politics like this ", meaning the choice to be visibly involved in party politics. The fact that he specifically supports the Green Party seems to make a difference in his eyes, as it is described as far more acceptable than standing with the Labour or Conservative parties. As was the case with other benefit concerts which Yorke took part in, it is unclear whether most fans in attendance were there to support environmental politics or to see the Radiohead frontman, but the latter explanation seems quite plausible. All in all, celebrity support was not enough to help Tony Juniper, since he came in fourth position with $7.6 \%$ of the vote in his constituency. The Green Party did, however, secure its first seat in the House of Commons that year as Caroline Lucas was elected as Member of Parliament for Brighton Pavilion. supporting a charitable cause to endorsing a specific political party. Such an evolution may appear all the more striking as Yorke had previously ruled out the possibility of using his fame to back a political party or even meet with a political leader. After all, many of Radiohead's politicised lyrics express nothing but mistrust of mainstream politics and of the government in general. Nonetheless, in hindsight, it appears that the issue of climate change provided Yorke and his bandmates with a sort of backdoor entrance onto the political stage, or rather, a way to legitimise political interest and participation, bearing in mind, as Yorke himself put it, that supporting the Green Party may be perceived as more legitimate for a rock star than endorsing one of the main two parties. More recently, Yorke has continued to indulge in the habit of issuing snide political comments, not necessarily on Radiohead's "Dead Air Space" blog (which has now disappeared from their official website), but rather on his own personal Twitter account. Twitter admittedly offers a very convenient platform for off-the-cuff, personal comments and one-liners, such as his reaction to the result of the 2015 General Election - "The City must be very pleased (spits)." ${ }^{139}$

\section{Conclusion: rock music as a form of activism?}

Radiohead's long career, spanning almost thirty years, has seen the band release nine successful albums, take part in hundreds of concerts and give at least as many interviews to the press, all of which have enabled the five musicians to voice political opinions, and to gradually develop the outlines of a genuine political ideology whose evolutions were triggered by significant events in the culture, economy and politics of contemporary Britain. Starting as five middle-class, university-educated musicians forming a band in the late 1980s, they have, since then, witnessed multiple transformations in British society and politics, from the twilight years of Thatcherism to Tony Blair's New Labour, and on to David Cameron's Broken Britain. As a rock band that has drawn their inspiration from their socio-political context, Radiohead's music inevitably reflected these social changes and, eventually, strengthened their opposition to them. What constituted, at first, the band's lyrical inspiration progressively turned into a political rationale and, later, to personal activism, especially in favour of environmental protection. But activism can also be defined as the act of expressing an opinion, supporting a cause, and encouraging others to share such beliefs, in the aim of improving a social, political, or environmental situation. Radiohead's politically-charged texts could thus be perceived as attempts at educating their listeners, or, at the very least, at drawing

Revue Française de Civilisation Britannique, XXII-3 | 2017 
their attention to a particular issue, without ever proving as overbearing as a full-on, explicit protest song.

Radiohead's political legacy and reputation as an activist band still needs to be appraised with respect to their highly respected status within the British rock scene. Assuming a political stance remains a potentially risky choice for such a high-profile band since it may alienate members of their audience, even though fans of Radiohead's challenging music are likely to share the musicians' middle-class education and environmental, political concerns. The main threat to a band's political integrity may then come from their record companies, which may estimate that activism could get in the way of commercial success. In that sense, it is not surprising to notice that Thom Yorke's fiercest protest messages made their way on to his band's blog after 2006, once Radiohead had fulfilled their contract with EMI and were therefore largely in control of the means of promotion of their music (as they notably did in 2007 by letting fans choose the amount they wanted to pay for their In Rainbows album). The "risks" taken by the band help appreciate their political contribution, even though the latter might appear slight in comparison of other artists'.

In the 1970s and 1980s, many high-profile acts did not shy away from full-on political action: for instance, punk-rock headliners The Clash took part in the Rock Against Racism campaign in 1976 and were known for their politically charged lyrics (which admittedly befitted punk rock's angry rhetorics better than Radiohead's experimental, introspective endeavours) without forsaking commercial success. ${ }^{40}$ Other examples of contemporary British musicians and activists include Billy Bragg, whose recordings include covers of famous socialist songs ("The Internationale", "The Red Flag"). Bragg's protest songs reflect his profound personal involvement in left-wing politics since he played benefit concerts during the Miners' strike and was part of the Red Wedge collective in the 1980s, organising concerts for the benefit of Neil Kinnock's Labour Party. An even stronger point of comparison can be found in the works of Manic Street Preachers, a Welsh rock band whose career overlaps Radiohead's and matches their level of success with no less than ten Top 10 albums. The Manic Street Preachers drew attention to their left-wing politics with a handful of chart-topping protest songs describing the plight of the working class ("A Design for Life", "If You Tolerate This Your Children Will be Next", or "Masses Against The Classes"). The fact that all three aforementioned acts lean towards the radical left serves up an interesting contrast to Radiohead's pro-environment stance, which may appear slightly tame - or at least in line with their middle-class upbringing - in comparison. All in all, Radiohead's political involvement seems less straightforward than some of its contemporaries', not because of a lack of personal involvement or awareness of political issues, but because of a purposeful choice to maintain a relative separation between music as a form of art (and introspection) and political participation.

Guillaume Clément est maître de conférences en anglais juridique à l'Université de Rennes 1. Il mène des travaux de recherche en civilisation britannique au sein de l'équipe d'accueil ACE (EA 1786 - Rennes 2) portant sur les interactions entre culture populaire et politique. Sa thèse de doctorat portait sur les rapports entre les partis politiques et les groupes de rock britanniques dans les années 1990 et 2000. 


\section{BIBLIOGRAPHY}

Adorno, Theodor, Aesthetic Theory (Minneapolis, University of Minnesota Press, 1988).

British Phonographic Industry, Certified Awards, http://www.bpi.co.uk/certified-awards/ search.aspx consulted 8 June 2016.

Campbell, Alastair, The Blair Years: Extracts from the Alastair Campbell Diaries (London, Hutchinson, 2007).

Ceccheto, Céline and Prat, Michel, La Chanson politique en Europe (Pessac, Presses universitaires de Bordeaux, 2008).

Citizen Insane, Follow Me Around, http://citizeninsane.eu/followmearound.html consulted 8 June $\underline{2016}$.

Clément, Guillaume, "Musique rock et politique au Royaume-Uni (1993-2007): De Cool Britannia à Broken Britain" (PhD dissertation, Université Paris-Sorbonne, 2014).

Clarke, Martin, Radiohead: Hysterical and Useless (London, Plexus, 1999).

Cohen, Nick, Cruel Britannia: Reports on the Sinister and the Preposterous (London, Verso, 1999).

Friends of the Earth, Big Names Back The Big Ask, 7 January 2008, https://www.foe.co.uk/news/ big_ask_live_vip_lounge consulted 30 April 2016.

Frith, Simon, "Écrire l'histoire de la musique populaire" in Hugh Dauncey and Philippe Le Guern (eds.), Stéréo: Sociologie Comparée des musiques populaires France / G.B. (Puceul, Mélanie Séteun, 2008), pp. 45-56.

Herman, Edward and Chomsky, Noam, Manufacturing Consent: The Political Economy of the Mass Media (New York, Pantheon, 1988).

Hutton, Will, The State We're In (London, Jonathan Cape, 1995).

Kent, Nick, "Happy now?" in Mojo, June 2001, p.62.

Kent, Nick, "Radiohead ou électro Thom?" in Rock \& Folk, September 2006, p.70.

Klein, Naomi, No Logo: Taking Aim at the Brand Bullies (New York, Picador, 1999).

New Musical Express, 14 March 1998.

Official UK Charts Company, Radiohead - Full Official Charts History, http:// www.officialcharts.com/artist/28161/radiohead/ consulted 8 June 2016.

Orwell, George, Nineteen Eighty-Four (Penguin Modern Classics) (London, Penguin, 2004).

Parry, Geraint, Moyser, George and Day, Neil, Political Participation and Democracy in Britain (Cambridge, Cambridge University Press, 1992).

Radiohead.com, Dead Air Space, http://www.radiohead.com/deadairspace consulted 30 April 2016.

\section{Discography:}

Radiohead, Pablo Honey (Parlophone, 1993). 
Radiohead, The Bends (Parlophone, 1995).

Radiohead, OK Computer (Parlophone, 1997).

Radiohead, Kid A (Parlophone, 2000).

Radiohead, Amnesiac (Parlophone, 2001).

Radiohead, Hail To The Thief(Parlophone, 2003).

Radiohead, In Rainbows (Parlophone, 2007).

Radiohead, The King of Limbs (Parlophone, 2011).

Radiohead, A Moon Shaped Pool (XL Recordings, 2016).

Thom Yorke, The Eraser (XL Recordings, 2006).

\section{NOTES}

1. Official UK Charts company, Radiohead - full official charts history, http:// www.officialcharts.com/artist/28161/radiohead consulted 8 June 2016.

2. British Phonographic Industry, Certified Awards, http://www.bpi.co.uk/certified-awards/ search.aspx consulted 8 June 2016.

3. Quoted in Joseph Tate (ed.), The Music and Art of Radiohead (Aldershot, Ashgate, 2005), p.180.

4. Simon Frith, "Écrire l'histoire de la musique populaire" in Hugh Dauncey and Philippe Le Guern (eds.), Stéréo: Sociologie comparée des musiques populaires - France / GB (Puceul, Mélanie Séteun, 2008), p.50.

5. Joseph Tate, op.cit., p.195.

6. Ibid.

7. Martin Clarke, Radiohead: Hysterical and Useless (London, Plexus, 1999), p.110.

8. Will Hutton, The State We're In (London, Jonathan Cape, 1995).

9. Edward Herman and Noam Chomsky, Manufactuing Consent: The Political Economy of the Mass Media (New York, Pantheon books, 1988). This book is referred to in Martin Clarke, op.cit., p.112.

10. Radiohead, "No Surprises", OK Computer (Parlophone, 1997).

11. Radiohead, "Fitter Happier", OK Computer (Parlophone, 1997).

12. Radiohead, "Electioneering", OK Computer (Parlophone, 1997).

13. Blair's attempts at securing several celebrity endorsements are well-documented in his former Director of Communications and Strategy's memoir: Alastair Campbell, The Blair Years (London, Hutchinson, 2007).

14. This expression was, it seems, coined by an American journalist (Stryker McGuire) in a piece he wrote for Newsweek in November 1996, entitles "London Reigns".

15. The phrase is borrowed from the title of a book published two years after OK Computer. In Cruel Britannia: Reports on the Sinister and the Preposterous (London, Verso, 1999), journalist Nick Cohen described the dark side of New Labour's rise to power.

16. Martin Clarke, op.cit., p.228.

17. Naomi Klein, No Logo: Taking Aim at the Brand Bullies (New York, Picador, 1999).

18. Radiohead, "You and Whose Army?", Amnesiac (Parlophone, 2001).

19. Quoted in Nick Kent, "Happy Now?", Mojo, June 2001, p.62.

20. This is a quote from John Lydon (the singer of punk rock band The Sex Pistols) which has very often been interpreted as part of punk rock's message of opposition to authority and mainstream politics. However, since Lydon uttered those famous words at the end of The Sex Pistols' last concert before disbanding in 1978 - following a period of strife between band members and 
disagreement regarding the band's subversive stance - the singer may then have meant to warn the public that his band's perception as an anti-establishment act had been blown out of proportion. Whatever interpretation should prevail, the choice of the NME to run this headline in 1998 both referenced punk rock's mistrust of the government and drew the public's attention to a potential misrepresentation of traditional left-wing ideals by the Labour government.

21. Other British rock bands were featured in this particular issue. For instance, Jarvis Cocker, the Pulp frontman, described the situation as "worse than if the Tories had got in, because with the Tories you would expect the same old shit to happen" (New Musical Express, 14 March 1998).

22. While this particular show took place two years after Amnesiac's release, multiple hints in the band's biographies and official website indicate that "Follow Me Around" originated in the Amnesiac recording sessions. A well-documented website curated by a group of fans relates the song's genesis, with early performances and references appearing on Radiohead's website as early as 1999 (Citizen Insane, Follow Me Around, http://citizeninsane.eu/followmearound.html consulted 8 June 2016).

23. Radiohead, "2+2=5", Hail to the Thief (Parlophone, 2003).

24. George Orwell, Nineteen Eighty-Four (Penguin Modern Classics) (London, Penguin, 2004). Other Orwellian references pervade Radiohead's work, for instance one of OK Computer's track, entitled "Karma Police" is an allusion to the "thought police" which is seen at work in Nineteen Eighty-Four

25. Thom Yorke, "Harrowdown Hill", The Eraser (XL Recordings, 2006).

26. Michel Prat, in Céline Ceccheto and Michel Prat (eds.), La Chanson Politique en Europe (Pessac, Presses Universitaires de Bordeaux, 2008), p.9.

27. Ibid., p.10.

28. These forms of political action are taken from Geraint Parry, George Moyser and Neil Day's study carried out in Political Participation and Democracy in Britain (Cambridge, Cambridge University Press, 1992, p.44), in which the authors propose a scale of political participation based on the percentage of the British population that took part in them. For instance, the most widespread form of political participation in Britain remains voting in a General Election (82.5\%) whereas only $5.2 \%$ took part in a protest march.

29. Martin Clarke, op.cit., pp.189, 206.

30. Several examples of fundraising rock festivals come to mind, such as Live Aid in 1985 and its follow-up Live 8 twenty years later. Both events gathered household names in British rock like Queen, David Bowie, Paul McCartney, Coldplay and Muse.

31. Quoted in Nick Kent, "Radiohead ou électro Thom", Rock \& Folk, September 2006, p.70.

32. Radiohead - Dead Air Space, Good Evening, 28 September 2005, http://www.radiohead.com/ deadairspace/050928 consulted 30 May 2016. Prior to the release of A Moon Shaped Pool, Radiohead deleted all existing content from their official website, which, as of June 2016, solely consists of material related to their latest album. Consequently, many of Thom Yorke's blog posts referenced here are unlikely to be available online anymore. A copy of these messages can nonetheless be found in the appendix to my PhD dissertation 'Musique Rock et politique au Royaume-Uni (1993-2007): de Cool Britannia à Broken Britain' (Université Paris-Sorbonne, 2014, pp.443-446).

33. Friends of the Earth, Big Names Back The Big Ask, 7 January 2008, https://www.foe.co.uk/news/ big_ask_live_vip_lounge consulted 30 April 2016.

34. Radiohead - Dead Air Space, Nuclear Power No Thanks, 9 November 2009, http:// www.radiohead.com/deadairspace/091109/nuclear-power-no-thanks consulted 30 April 2016.

35. In 2010, as part of my doctoral research, I sent an online questionnaire to a small sample of Radiohead fans in order to assess their response to Thom Yorke's involvement alongside Friends of the Earth. The entire study and its conclusions are available in my $\mathrm{PhD}$ dissertation (pp. 325-345). A majority of the 40 respondents indicated that they were extremely unlikely to change 
political allegiances simply on account of their favourite band's leanings. Yet, a handful of respondents hinted that Yorke's political messages could influence them slightly, even by simply drawing their attention to political issues that they might, in turn, research personally.

36. Radiohead - Dead Air Space, A Rant And Some Other Stuff, 19 November 2009, http:// www.radiohead.com/deadairspace/091119/A-rant-and-some-other-stuff consulted 30 April 2016. 37. Radiohead - Dead Air Space, Not Finished, 18 December 2009, http://www.radiohead.com/ deadairspace/091218/not-finished consulted 30 April 2016.

38. Radiohead.com - Dead Air Space, Tony Juniper / Cambridge Corn Exchange, 10 February 2010, http://radiohead.com/deadairspace/100210/Tony-Juniper-Cambridge-Corn-Exchange consulted 30 April 2016.

39. Twitter @thomyorke, Thom Yorke, 8 May 2015, https://twitter.com/thomyorke consulted 9 May 2015.

40. Some of The Clash's best-known song titles reflect their taste for radical politics, for instance "White Riot", "English Civil War", "Revolution Rock", "Ivan Meets G.I. Joe", "The Guns of Brixton", and "Know Your Rights". The political nature of their songs did not prevent The Clash from scoring three Top 10 albums (Give 'Em Enough Rope, London Calling, and Combat Rock).

\section{ABSTRACTS}

One of the most commercially and critically successful contemporary rock bands in Britain, Radiohead became famous for expanding their horizons beyond guitar-based rock music. In the course of their thirty-year career, as their music became more complex, Radiohead evolved into a politicized band as well, as singer and songwriter Thom Yorke found inspiration in the sociopolitical context of the time. While the songs of OK Computer (1997) offered a vision of British society at odds with the concept of Cool Britannia, later albums featured implicit criticisms aimed at the New Labour government. Moreover, Yorke often took to his band's official website in order to express his outrage at the British government's environmental policy, lending his support to organisations like Friends of the Earth and the Green Party. The analysis of some of Radiohead's best-known songs provides an outline of the band's political ideology, which was, in turn, fulfilled by some of the band members' activism. Radiohead can thus be defined as an activist band, not only due to the personal political commitment of some of the musicians, but also through their musical output, which provides a way for their audience to get acquainted with socio-political issues.

Radiohead est un groupe de rock britannique contemporain à succès, salué par la critique pour son goût de l'expérimentation. Les sujets abordés par les textes du parolier et chanteur Thom Yorke révèlent un contenu politique dès le milieu des années 1990. L'album OK Computer (1997) propose une vision des plus mornes de la société britannique, aux antipodes du concept de Cool Britannia pourtant en vogue à l'époque, alors que les albums suivants dénoncent, parfois à demimot, certains aspects de la politique du gouvernement travailliste. En parallèle, Thom Yorke utilise fréquemment le site internet de Radiohead pour afficher son mécontentement vis-à-vis de la politique environnementale britannique, et va jusqu'à soutenir ouvertement l'association Friends of the Earth, puis le parti écologique britannique. L'analyse des paroles des chansons de Radiohead permet d'esquisser les contours d'une idéologie politique, qui est concrétisée dans l'action et le soutien politiques à l'œuvre chez certains membres du groupe. Radiohead est ici 
défini comme un groupe militant, à la fois en attirant l'attention de son public sur des questions socio-politiques par le biais de sa musique, et en s'engageant en politique à titre personnel.

INDEX

Mots-clés: Radiohead, engagement, Parti travailliste, Ecologie, chansons politiques, musique rock

Keywords: Radiohead, activism, New Labour, environmental politics, rock music

\section{AUTHOR}

\section{GUILLAUME CLÉMENT}

Université Rennes I, équipe ACE 